\title{
LIFESTYLE RISK FACTORS AND BONE MASS IN RECURRENT STONE-FORMING PATIENTS: A CROSS-SECTIONAL STUDY IN 144 SUBJECTS
}

\author{
Ivana Marić ${ }^{1,2}$, Tomislav Kizivat ${ }^{1,2}$, Martina Smolić 2 , Robert Smolić ${ }^{1,2}$, Teuta Opačak-Bernardi²,

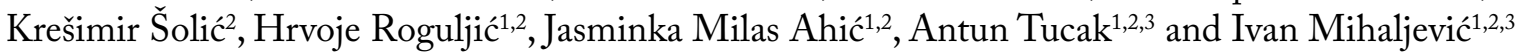 \\ ${ }^{1}$ Clinical Institute of Nuclear Medicine and Radiation Protection, Osijek University Hospital Centre, Osijek, Croatia; \\ ${ }^{2}$ Department of Mineral Research, Faculty of Medicine, Josip Juraj Strossmayer University of Osijek, Osijek, Croatia; \\ ${ }^{3}$ Croatian Academy of Medical Sciences, Zagreb, Croatia
}

\begin{abstract}
SUMMARY - Patients with urolithiasis, particularly hypercalciuria, may have reduced bone mineral density (BMD). There are numerous risk factors contributing to reduction of BMD such as advanced age, sedentary lifestyle, smoking, low calcium intake, etc. The aim of our study was to investigate the association of lifestyle risk factors and daily intake of milk and dairy products with determinants of BMD in a group of recurrent calcium stone formers (RSF) compared with healthy subjects (HS). The study was carried out at the Department of Mineral Research, Faculty of Medicine in Osijek, Croatia. The study included 144 subjects, i.e. 56 RSF and 78 HS. BMD was assessed by dualenergy $\mathrm{x}$-ray absorptiometry. A standard self-reported questionnaire was used to collect data on lifestyle risk factors. Current dietary intake was assessed by personal interview that included questions about milk and dairy product intake. Low BMD was observed in $44.64 \%$ of RSF and $35.90 \%$ of HS. RSF consumed significantly less milk and dairy products than HS. Calcium restriction in dietary recommendations might be unnecessary due to the impact on bone mineral loss in RSF and dualenergy $x$-ray absorptiometry should be included in the routine evaluation of RSF.
\end{abstract}

Key words: urolithiasis, bone mineral density, body weight, body mass index, physical activity, smoking, calcium intake

\section{Introduction}

Urolithiasis remains a common health, social and economic problem of modern society and occurs at least once in life in $15 \%$ of Caucasian men and $6 \%$ of women $^{1,2}$, with a recurrence rate of around $50 \%$ over 10 years and $75 \%$ over 15 and 20 years, respectively ${ }^{3,4}$. Recurrent urolithiasis is defined as three or more episodes of kidney stones in a 5 -year period ${ }^{5}$. The prevalence of urolithiasis has increased in recent decades in both males and females ${ }^{6}$. Calcium oxalate and calcium phosphate are the most common types of kidney

Correspondence to: Prof. Ivan Mihaljevic, $M D, P h D$, Clinical Institute of Nuclear Medicine and Radiation Protection, Osijek University Hospital Centre, Josipa Huttlera 4, HR-31000 Osijek, Croatia E-mail: ivanm2712@gmail.com

Received November 9, 2017, accepted June 13, 2018 stones, accounting for $>80 \%$ of stones ${ }^{7}$. Idiopathic hypercalciuria is the most prevalent abnormality in calcium kidney stone formers; metabolic analyses performed in these patients yielded a rate of hypercalciuria of $60 \%^{8}$. In practice, hypercalciuria is defined as daily calcium excretion of over $250 \mathrm{mg} /$ day in women and $300 \mathrm{mg} /$ day in men ${ }^{9}$.

The association between urolithiasis and bone mineral density (BMD) is already known and according to several clinical and epidemiological studies performed in recurrent calcium stone formers (RSF), patients with urolithiasis, particularly hypercalciuria, may have reduced bone density. Bone loss in these patients is caused by increased resorption and/or decreased bone formation ${ }^{10-13}$.

Dietary habits and lifestyle play an important role in the formation of kidney stones, as well as in BMD. 
The aim of our study was to investigate the association of age, anthropometric parameters and lifestyle factors with determinants of BMD in a group of RSF compared with healthy subjects (HS).

\section{Material and Methods}

\section{Subjects}

We investigated 56 unrelated patients with recurrent urinary stone formation who consecutively visited the Department of Urology, Osijek University Hospital Centre. The diagnosis of recurrent urolithiasis was based on the history of two or more episodes of renal colic, radiographic evidence of stones and report of stone analysis, and only patients with confirmed calcium oxalate urolithiasis were included in the study.

Control group consisted of 78 patients without a known history of renal stone disease and with ultrasound confirmation of the absence of kidney stones who were undergoing osteoporosis evaluation at the Department of Mineral Research, Faculty of Medicine in Osijek. The following subjects were excluded: subjects with gastrointestinal diseases (ulcerative colitis, malabsorption syndrome, chronic pancreatitis), renal tubular acidosis, pregnant women, subjects with primary hyperparathyroidism and other diseases affecting calcium metabolism (hyperthyroidism, acromegaly, sarcoidosis, diabetes or cancer), and those using medications such as corticosteroids, barbiturates, estrogen, calcium or vitamin D. A written informed consent was obtained from all participants and the study was approved by the Ethics Committee of the Faculty of Medicine, Osijek, Croatia.

\section{Anthropometric measurements}

Body weight and height were measured with subjects wearing light clothing and no shoes. Body mass index (BMI) was calculated as weight $(\mathrm{kg})$ divided by squared height $\left(\mathrm{m}^{2}\right) ; B M I \geq 30 \mathrm{~kg} / \mathrm{m}^{2}$ was used as a parameter for obesity and BMI $>24.9 \mathrm{~kg} / \mathrm{m}^{2}$ as excess weight ${ }^{14}$.

\section{Lifestyle risk factors}

Data on lifestyle (smoking status, current physical activity, sports activity in the past) were collected by use of standard self-reported questionnaire. The questions regarding sports activity in the past included specific questions about frequency and duration of previ- ous sports activities (in hours) on a weekly basis (performing regular exercise for more than 30 minutes two times a week). Current physical activities (walking, biking, manual work, etc.) were classified into three levels, as follows: very active ( $\geq 4.5$ hours per week), moderately active (1.5-4.5 hours per week), and less active ( $<1.5$ hours per week).

Smoking habit was categorized as current, past or never used. Current dietary intake was assessed by personal interview that included questions about milk and dietary product intake. Answers were classified into three groups, as follows: never or less than once a day, once a day, and more than once a day.

\section{Bone density measurement}

Bone mineral density and bone mineral content (BMC) were assessed by dual-energy x-ray absorptiometry (Lunar Prodigy, GE Healthcare, USA). BMD and $\mathrm{BMC}$ measurements were performed at lumbar spine and femoral neck. Areal BMD was expressed in $\mathrm{g} / \mathrm{cm}^{2}$ and standard deviation from the young normal mean (T-score) based on the World Health Organization (WHO) criteria. A score from -1 to $-2.5 \mathrm{SD}$ below the norm indicates low bone mass or osteopenia, and a score of equal or more than $-2.5 \mathrm{SD}$ below the norm indicates osteoporosis ${ }^{14}$.

\section{Statistical analysis}

Categorical data were presented as absolute and relative frequencies, and numerical data as mean with standard deviation or median with interquartile range. Differences between categories were tested with $\chi^{2}$ test and comparison between groups was done with the independent samples T-test or Mann-Whitney U Test. Statistical analyses were conducted using SAS software (version 8.02, SAS Institute Inc., Cary, NC, USA) with the level of statistical significance set at $\mathrm{p}<0.05$.

\section{Results}

Clinical characteristics of RSF and HS groups are presented in Table 1.

The RSF group included $51.79 \%$ of men and $48.21 \%$ of women; there was no statistically significant difference according to age or sex between RSF and HS groups. However, RSF had higher BMI $\left(27.56 \mathrm{~kg} / \mathrm{m}^{2}\right.$; interquartile range $25.27 \mathrm{~kg} / \mathrm{m}^{2}$ to $29.73 \mathrm{~kg} / \mathrm{m}^{2}$ ) compared to HS $\left(26.81 \mathrm{~kg} / \mathrm{m}^{2}\right.$; interquartile range 23.92 
Table 1. Age and anthropometric parameter distribution of recurrent stone formers (RSF) and healthy subjects (HS)

\begin{tabular}{|c|c|c|c|}
\hline & $\operatorname{RSF}(\mathrm{n}=56)$ & HS (n=78) & $\mathrm{p}$ \\
\hline $\begin{array}{l}\text { Age (yrs) } \\
\text { mean } \pm S D\end{array}$ & $49.16 \pm 11.59$ & $52.51 \pm 7.73$ & 0.116 \\
\hline $\begin{array}{l}\text { Height }(\mathrm{cm}) \\
\text { mean } \pm S D\end{array}$ & $170.91 \pm 9.66$ & $167.64 \pm 6.81$ & 0.030 \\
\hline $\begin{array}{l}\text { Weight }(\mathrm{kg}) \\
\text { mean } \pm \mathrm{SD}\end{array}$ & $80.57 \pm 12.83$ & $75.78 \pm 14.54$ & 0.050 \\
\hline $\begin{array}{l}\mathrm{BMI}\left(\mathrm{kg} / \mathrm{m}^{2}\right) \\
\text { median } \\
\left(25^{\text {th }} \text { percentile, }\right. \\
\left.75^{\text {th }} \text { percentile }\right)\end{array}$ & $\begin{array}{l}27.56 \\
(25.27,29.73)\end{array}$ & $\begin{array}{l}26.81 \\
(23.92,29.73)\end{array}$ & $0.283^{*}$ \\
\hline
\end{tabular}

Independent samples T-test; *Mann-Whitney U test

Table 2. Distribution of T scores, bone mineral density (BMD) and bone mineral contents (BMC) for lumbar spine and femoral neck in recurrent stone formers (RSF) and healthy subjects (HS)

\begin{tabular}{|c|c|c|c|}
\hline & $\operatorname{RSF}(n=56)$ & HS $(n=78)$ & $p$ \\
\hline $\begin{array}{l}\text { T-score } \\
\text { (lumbar spine) } \\
\text { median } \\
\text { (25 } \\
75^{\text {th }} \text { percentile, } \\
\text { percentile) }\end{array}$ & $\begin{array}{l}-0.25 \\
(-1.20,0.70)\end{array}$ & $\begin{array}{l}0.00, \\
(-0.70 ; 1.00)\end{array}$ & $0.131^{*}$ \\
\hline $\begin{array}{l}\text { T-score } \\
\text { (femoral neck) } \\
\text { median } \\
\text { ( } 25^{\text {th }} \text { percentile, } \\
75^{\text {th }} \text { percentile) }\end{array}$ & $\begin{array}{l}-0.50 \\
(-1.28,0.00)\end{array}$ & $\begin{array}{l}-0.50 \\
(-1.30 \\
-0.08)\end{array}$ & $0.678^{*}$ \\
\hline $\begin{array}{l}\text { BMD } \\
\text { (lumbar spine) } \\
\text { mean } \pm \text { SD }\end{array}$ & $1.16 \pm 0.16$ & $1.21 \pm 0.18$ & 0.109 \\
\hline $\begin{array}{l}\text { BMD } \\
\text { (femoral neck) } \\
\text { mean } \pm S D\end{array}$ & $0.95 \pm 0.12$ & $0.98 \pm 0.14$ & 0.148 \\
\hline $\begin{array}{l}\mathrm{BMC} \\
\text { (lumbar spine) } \\
\text { mean } \pm \mathrm{SD}\end{array}$ & $70.61 \pm 14.50$ & $71.33 \pm 16.43$ & 0.792 \\
\hline $\begin{array}{l}\text { BMC } \\
\text { (femoral neck) } \\
\text { median } \\
\text { ( } 25^{\text {th }} \text { percentile, } \\
75^{\text {th }} \text { percentile) }\end{array}$ & $\begin{array}{l}4.97 \\
(4.40,5.83)\end{array}$ & $\begin{array}{l}5.00 \\
(4.50,5.54)\end{array}$ & $0.883^{*}$ \\
\hline
\end{tabular}

Independent samples T-test; *Mann-Whitney U test

$\mathrm{kg} / \mathrm{m}^{2}$ to $29.73 \mathrm{~kg} / \mathrm{m}^{2}$ ) (Mann-Whitney U test, $\mathrm{p}=0.283$ ).

Low BMD was observed in $44.64 \%$ of RSF (osteoporosis $20 \%$ ) and $35.90 \%$ of HS (osteoporosis $10.71 \%$ ).
Table 3. Demographic and lifestyle risk factors in recurrent stone formers (RSF) and healthy subjects (HS)

\begin{tabular}{|c|c|c|c|}
\hline & RSF n (\%) & $\mathrm{HS}$ n (\%) & $\mathrm{p}$ \\
\hline \multicolumn{4}{|l|}{ Age group (yrs): } \\
\hline$\leq 60$ & $47(83.93)$ & $67(85.90)$ & \multirow[b]{2}{*}{0.752} \\
\hline$>60$ & $9(16.07)$ & $11(14.10)$ & \\
\hline \multicolumn{4}{|l|}{ Body mass index: } \\
\hline$\leq 24.9$ & $13(23.22)$ & $27(34.62)$ & \multirow[b]{3}{*}{0.258} \\
\hline $25.0-29.9$ & $32(57.14)$ & $34(43.59)$ & \\
\hline$\leq 30.0$ & $11(19.64)$ & $17(21.79)$ & \\
\hline \multicolumn{4}{|l|}{ Smoking: } \\
\hline Current smoker & $16(28.57)$ & $28(35.90)$ & \multirow[b]{3}{*}{0.633} \\
\hline Past smoker & $13(23.22)$ & $18(23.08)$ & \\
\hline Never smoked & $27(48.21)$ & $32(41.03)$ & \\
\hline \multicolumn{4}{|c|}{ Current physical activity: } \\
\hline Very active & $3(5.36)$ & $10(12.82)$ & \multirow[b]{3}{*}{0.349} \\
\hline Moderately active & $39(69.64)$ & $49(62.82)$ & \\
\hline Less active & $14(25.00)$ & $19(24.36)$ & \\
\hline \multicolumn{4}{|c|}{ Previous sports activity: } \\
\hline Yes & $27(48.21)$ & $30(38.46)$ & \multirow[b]{2}{*}{0.260} \\
\hline No & $29(51.79)$ & $48(61.54)$ & \\
\hline \multicolumn{4}{|l|}{ Milk consumption: } \\
\hline $\begin{array}{l}\text { Never/less than } \\
\text { once a day }\end{array}$ & $31(55.36)$ & $24(30.77)$ & \multirow[b]{3}{*}{0.017} \\
\hline Once a day & $17(30.35)$ & $37(47.43)$ & \\
\hline $\begin{array}{l}\text { More than once a } \\
\text { day }\end{array}$ & $8(14.29)$ & 17 (21.79) & \\
\hline \multicolumn{4}{|l|}{ Educational level: } \\
\hline $\begin{array}{l}\text { Elementary } \\
\text { school }\end{array}$ & $10(17.86)$ & $14(17.95)$ & \\
\hline High school & $29(51.79)$ & $31(39.74)$ & \\
\hline University & $17(30.35)$ & $33(42.31)$ & 0.316 \\
\hline Total & $56(100.00)$ & $78(100.00)$ & \\
\hline
\end{tabular}

$\chi^{2}$-test

BMD was lower in RSF at all measured sites but without statistical significance (Table 2).

A significant difference was obtained for more than once daily milk consumption between RSF (14.29\%) and HS (21.79\%) ( $\chi^{2}$-test, $\left.\mathrm{p}=0.017\right)$. Smoking habit, current physical activity, previous sports activity and level of education did not differ significantly between the two groups (Table 3 ).

\section{Discussion}

We investigated the influence of lifestyle factors on $\mathrm{BMD}$ in RSF. Although kidney stones are more com- 
mon in men than in women, male predominance was not confirmed in our study. However, in our study RSF had a significantly higher body weight than HS and this finding is consistent with previous studies ${ }^{15}$.

Recent evidence shows that an increase in body weight and BMI is associated with the increasing risk of urolithiasis. Weight gain from early adulthood was associated with an increased risk of kidney stones in both men and women ${ }^{15}$. Studies in patients with urolithiasis showed higher BMI to be significantly associated with lower urinary $\mathrm{pH}$ level ${ }^{16-18}$. The reasons for progressive decline in urine $\mathrm{pH}$ with increasing $\mathrm{BMI}$ in urolithiasis patients have not been defined yet. Obesity is associated with insulin resistance and hyperinsulinemia, metabolic disorders known to have a strong influence on urine composition, thus increasing the kidney fractional excretion of calcium, uric acid and oxalate, resulting in lower urinary $\mathrm{pH}^{16,19,20}$. A high animal protein diet results in subtle metabolic acidosis and potentially could lead to increased bone turnover. Metabolic acidosis caused by the high protein diet induces the release of bone calcium to buffer acid load, consequently leading to hypercalciuria and bone loss ${ }^{21}$.

On the other hand, decreased bone mass in $\mathrm{pa}^{-}$ tients with urolithiasis was demonstrated in several clinical and epidemiological studies ${ }^{22-25}$.

In our study, a significant bone loss in patients with urolithiasis was confirmed by the rate of osteoporosis of $20 \%$ and $10.71 \%$ in the RSF and HS group, respectively.

In their study performed using dual-energy x-ray absorptiometry, Trinchieri et al. found that BMD was lower in hypercalciuric patients $(57 \%)$ than in normocalciuric patients (44\%), while the rate of osteopenia and osteoporosis in hypercalciuric patients was 48 and $6 \%$, respectively ${ }^{26}$. In their study that included normocalciuric patients with recurrent calcium stones, Tugcu et al. found BMD to be decreased in $76.7 \%$ and $20.0 \%$ of patients and healthy subjects, respectively ${ }^{10}$. In a follow up study, Cvijetic et al. also found greater BMD reduction in stone formers as compared with controls ${ }^{27}$.

Milk and dairy products are primary sources of calcium and have an impact on bone density ${ }^{28,29}$. According to our results, HS consumed significantly more milk and dairy products than RSF. These findings are interesting and intriguing because a calcium restricted diet which is often recommended in urolithiasis patients might increase bone resorption leading to bone $\operatorname{loss}^{30,31}$.
However, reduction of calcium supply increases oxalate absorption and enhances urinary saturation with oxalate salts, which might explain why low-calcium diet increases the risk of calcium oxalate stone formation ${ }^{32}$. This point has been supported by another study where stone-formers reported reduced dietary calcium intakes when factored for body weight but urinary calcium excretion was comparable between the two groups suggesting that stone formers were in more negative calcium balance compared to non-stone-formers ${ }^{33}$.

Borghi et al. found that in men with recurrent calcium oxalate stones and hypercalciuria, low animal protein and salt diet in combination with normal calcium intake had a protective effect in the prevention of stone recurrence ${ }^{34}$. Similar results were obtained by other research groups ${ }^{35,36}$. Therefore, obesity and low calcium diet in RSF might explain the high rate of decreased BMD in our study as well.

On the other hand, in our study, smoking habit, physical activity and level of education were not significantly different between RSF and HS. These data are concordant with the findings of several research groups which do not support the possible association between smoking and urinary tract stones ${ }^{37,38}$.

However, there are research groups that might argue these findings since their data claim that cigarette smoking may induce urolithiasis by decreasing urinary flow and increasing serum cadmium in healthy subjects $^{39,40}$. Also, there are some reports suggesting that adult smokers had twice the odds of having urinary stones (OR 2.1, 95\% CI 1.1-4.0) as compared with age-matched non-stone formers ${ }^{41}$. In contrast, cigarette smoking is associated with low BMD and increased risk of fracture in both genders ${ }^{42,43}$. Although the underlying mechanisms of the association between smoking and low BMD are not completely known, this could be attributed to the adverse effect of smoking on skeletal remodeling and bone cells ${ }^{44}$, decreased intestinal calcium absorption due to smoking ${ }^{45}$, and its impact on sex hormones ${ }^{46}$. There are limited literature data on the impact of physical activity on the formation of kidney stones but the importance of physical activity in the prevention of many chronic diseases is well known ${ }^{47,48}$.

In a study that included 84,225 postmenopausal women, Sorensen et al. found that physical activity might reduce the risk of incident kidney stones. They found that the intensity of the activity was not impor- 
tant because only mild to moderate weekly activity was enough to be protective against kidney stone formation ${ }^{49}$. These results are in contrast to a recent study that examined the association between physical activity and incidence of kidney stones. In this prospective cohort study, age-adjusted and multivariate-adjusted analyses failed to confirm significant associations between physical activity and kidney stones ${ }^{50}$. Although physical inactivity appears to be a risk factor for kidney stones, the pathogenetic mechanisms remain elusive and need to be further investigated.

Gur et al. report on a significant correlation between educational level and BMD. In their study, the prevalence of osteoporosis showed an inverse relationship with the level of education, ranging from $18.6 \%$ for high educated to $34.4 \%$ for low educated women ${ }^{51}$. Although the mechanisms of association between educational level and low BMD remain partly unexplained, the higher BMD values in the highest education group may be attributed to sufficient calcium intake.

Our study had several limitations. Daily fluid, salt and protein intakes as important factors for stone disease were not assessed. An additional limitation of the study may be that the questionnaire used provided limited information on the quantity of calcium intake, as well as on precise physical activities of our participants. These limitations should be taken into account on interpreting the study results.

These results suggested that patients with recurrent calcium stones had greater BMD decline compared to patients without lithiasis. The most important predictors of BMD in our study were body weight and dairy intake. Therefore, BMD analyses should be included in the routine evaluation of RSF. However, calcium restriction in dietary recommendations might be unnecessary due to the impact on bone mineral loss in RSF.

\section{Acknowledgment}

The study was supported by grant no. 2192192190-2182 from the Ministry of Science, Education and Sports, Republic of Croatia.

\section{References}

1. Bihl G, Meyers A. Recurrent renal stone disease - advances in pathogenesis and clinical management. Lancet. 2001;358 (9282):651-6. doi: 10.1016/S0140-6736(01)05782-8. PubMed PMID: 11530173.
2. Uribarri J, Oh MS, Carroll HJ. The first kidney stone. Ann Intern Med. 1989;111(12):1006-9. PubMed PMID: 2688503.

3. Tucak A, Babić-Ivančić V, Dekanić-Ožegović D, Karner I, Zorić I. Bone mineral density and calcium metabolism in patients with urolithiasis. Period Biol. 2000;102:77-81.

4. Coe FL, Evan A, Worcester E. Kidney stone disease. J Clin Invest. 2005;115(10):2598-608. doi: 10.1172/JCI26662. PubMed PMID: 16200192; PubMed Central PMCID: PMCPMC1236703.

5. Gambaro G, Vezzoli G, Casari G, Rampoldi L, D’Angelo A, Borghi L. Genetics of hypercalciuria and calcium nephrolithiasis: from the rare monogenic to the common polygenic forms. Am J Kidney Dis. 2004;44(6):963-86. PubMed PMID: 15558518.

6. Stamatelou KK, Francis ME, Jones CA, Nyberg LM, Curhan GC. Time trends in reported prevalence of kidney stones in the United States: 1976-1994. Kidney Int. 2003;63(5):1817-23. doi: 10.1046/j.1523-1755.2003.00917.x. PubMed PMID: 12675858 .

7. Caudarella R, Vescini F, Buffa A, La Manna G, Stefoni S. Osteoporosis and urolithiasis. Urol Int. 2004;72 Suppl 1:17-9. doi: 10.1159/000076585. PubMed PMID: 15133327.

8. Worcester EM, Coe FL. Clinical practice. Calcium kidney stones. N Engl J Med. 2010;363(10):954-63. doi: 10.1056/ NEJMcp1001011. PubMed PMID: 20818905; PubMed Central PMCID: PMCPMC3192488.

9. Worcester EM, Coe FL. New insights into the pathogenesis of idiopathic hypercalciuria. Semin Nephrol. 2008;28(2):120-32. doi: 10.1016/j.semnephrol.2008.01.005. PubMed PMID: 18359393; PubMed Central PMCID: PMCPMC2362396.

10. Tugcu V, Ozbek E, Aras B, Ozbay B, Islim F, Tasci AI. Bone mineral density measurement in patients with recurrent normocalciuric calcium stone disease. Urol Res. 2007;35(1):29-34. Epub 2006/12/12. doi: 10.1007/s00240-006-0074-0. PubMed PMID: 17160655.

11. Zerwekh JE. Bone disease and idiopathic hypercalciuria. Semin Nephrol. 2008;28(2):133-42. doi: 10.1016/j.semnephrol. 2008.01.006. PubMed PMID: 18359394; PubMed Central PMCID: PMCPMC2366793.

12. Gomes SA, dos Reis LM, Noronha IL, Jorgetti V, Heilberg IP. RANKL is a mediator of bone resorption in idiopathic hypercalciuria. Clin J Am Soc Nephrol. 2008;3(5):1446-52. Epub 2008/05/14. doi: 10.2215/CJN.00240108. PubMed PMID: 18480302; PubMed Central PMCID: PMCPMC2518782.

13. Sakhaee K, Maalouf NM, Kumar R, Pasch A, Moe OW. Nephrolithiasis-associated bone disease: pathogenesis and treatment options. Kidney Int. 2011;79(4):393-403. Epub 2010/12/01. doi: 10.1038/ki.2010.473. PubMed PMID: 21124301; PubMed Central PMCID: PMCPMC3088506.

14. Physical status: the use and interpretation of anthropometry. Report of a WHO Expert Committee. World Health Organ Tech Rep Ser. 1995;854:1-452. PubMed PMID: 8594834.

15. Taylor EN, Stampfer MJ, Curhan GC. Obesity, weight gain, and the risk of kidney stones. JAMA. 2005;293(4):455-62. doi: 10.1001/jama.293.4.455. PubMed PMID: 15671430. 
16. Li WM, Chou YH, Li CC, Liu CC, Huang SP, Wu WJ, et al. Association of body mass index and urine $\mathrm{pH}$ in patients with urolithiasis. Urol Res. 2009;37(4):193-6. Epub 2009/05/26. doi: 10.1007/s00240-009-0194-4. PubMed PMID: 19468724.

17. Negri AL, Spivacow FR, Del Valle EE, Forrester M, Rosende G, Pinduli I. Role of overweight and obesity on the urinary excretion of promoters and inhibitors of stone formation in stone formers. Urol Res. 2008;36(6):303-7. Epub 2008/11/05. doi: 10.1007/s00240-008-0161-5. PubMed PMID: 18985334.

18. Maalouf NM, Sakhaee K, Parks JH, Coe FL, Adams-Huet B, Pak CY. Association of urinary $\mathrm{pH}$ with body weight in nephrolithiasis. Kidney Int. 2004;65(4):1422-5. doi: 10.1111/ j.1523-1755.2004.00522.x. PubMed PMID: 15086484.

19. Jeong IG, Kang T, Bang JK, Park J, Kim W, Hwang SS, et al. Association between metabolic syndrome and the presence of kidney stones in a screened population. Am J Kidney Dis. 2011;58(3):383-8. Epub 2011/05/26. doi: 10.1053/j.ajkd.2011. 03.021. PubMed PMID: 21620546.

20. Chou YH, Su CM, Li CC, Liu CC, Liu ME, Wu WJ, et al. Difference in urinary stone components between obese and non-obese patients. Urol Res. 2011;39(4):283-7. Epub 2010/ 12/16. doi: 10.1007/s00240-010-0344-8. PubMed PMID: 21161648 .

21. Krieger NS, Frick KK, Bushinsky DA. Mechanism of acid-induced bone resorption. Curr Opin Nephrol Hypertens. 2004; 13(4):423-36. PubMed PMID: 15199293.

22. Vezzoli G, Rubinacci A, Bianchin C, Arcidiacono T, Giambona $\mathrm{S}$, Mignogna $\mathrm{G}$, et al. Intestinal calcium absorption is associated with bone mass in stone-forming women with idiopathic hypercalciuria.Am J Kidney Dis. 2003;42(6):1177-83.PubMed PMID: 14655189.

23. Caudarella R, Vescini F, Buffa A, Sinicropi G, Rizzoli E, La Manna $G$, et al. Bone mass loss in calcium stone disease: focus on hypercalciuria and metabolic factors. J Nephrol. 2003;16 (2):260-6. PubMed PMID: 12768074.

24. Fabris A, Ferraro PM, Comellato G, Caletti C, Fantin F, Zaza $\mathrm{G}$, et al. The relationship between calcium kidney stones, arterial stiffness and bone density: unraveling the stone-bone-vessel liaison. J Nephrol. 2015;28(5):549-55. Epub 2014/09/30. doi: 10.1007/s40620-014-0146-0. PubMed PMID: 25266216.

25. Shavit L, Girfoglio D, Vijay V, Goldsmith D, Ferraro PM, Moochhala SH, et al. Vascular calcification and bone mineral density in recurrent kidney stone formers. Clin J Am Soc Nephrol. 2015;10(2):278-85. Epub 2015/01/29. doi: 10.2215/ CJN.06030614. PubMed PMID: 25635036; PubMed Central PMCID: PMCPMC4317743.

26. Trinchieri A, Nespoli R, Ostini F, Rovera F, Zanetti G, Pisani E. A study of dietary calcium and other nutrients in idiopathic renal calcium stone formers with low bone mineral content. J Urol. 1998;159(3):654-7. PubMed PMID: 9474119.

27. Cvijetic S, Füredi-Milhofer H, Babic-Ivancic V, Tucak A, Galic J, Dekanic-Ozegovic D. Bone mineral density loss in patients with urolithiasis: a follow-up study. Arch Med Res. 2002;33(2):152-7. PubMed PMID: 11886714.
28. Weaver CM. Calcium supplementation: is protecting against osteoporosis counter to protecting against cardiovascular disease? Curr Osteoporos Rep. 2014;12(2):211-8. doi: 10.1007/ s11914-014-0208-1. PubMed PMID: 24671370.

29. Rizzoli R. Dairy products, yogurts, and bone health. Am J Clin Nutr. 2014;99(5 Suppl):1256S-62S. Epub 2014/04/02. doi: 10.3945/ajcn.113.073056. PubMed PMID: 24695889.

30. Warensjö E, Byberg L, Melhus H, Gedeborg R, Mallmin H, Wolk A, et al. Dietary calcium intake and risk of fracture and osteoporosis: prospective longitudinal cohort study. BMJ. 2011; 342:d1473. Epub 2011/05/24. PubMed PMID: 21610048; PubMed Central PMCID: PMCPMC3101331.

31. Peterlik M, Kállay E, Cross HS. Calcium nutrition and extracellular calcium sensing: relevance for the pathogenesis of osteoporosis, cancer and cardiovascular diseases. Nutrients. 2013;5(1):302-27. Epub 2013/01/22. doi: 10.3390/nu5010302. PubMed PMID: 23340319; PubMed Central PMCID: PMCPMC3571650.

32. von Unruh GE, Voss S, Sauerbruch T, Hesse A. Dependence of oxalate absorption on the daily calcium intake. J Am Soc Nephrol. 2004;15(6):1567-73. PubMed PMID: 15153567.

33. Asplin JR, Bauer KA, Kinder J, Müller G, Coe BJ, Parks JH, et al. Bone mineral density and urine calcium excretion among subjects with and without nephrolithiasis. Kidney Int. 2003; 63(2):662-9. doi: 10.1046/j.1523-1755.2003.00763.x. PubMed PMID: 12631132.

34. Borghi L, Schianchi T, Meschi T, Guerra A, Allegri F, Maggiore $\mathrm{U}$, et al. Comparison of two diets for the prevention of recurrent stones in idiopathic hypercalciuria. N Engl J Med. 2002;346(2):77-84. doi: 10.1056/NEJMoa010369. PubMed PMID: 11784873.

35. Taylor EN, Fung TT, Curhan GC. DASH-style diet associated with reduced risk for kidney stones. J Am Soc Nephrol. 2009; 20(10):2253-9. Epub 2009/08/13. doi: 10.1681/ASN.200903 0276. PubMed PMID: 19679672; PubMed Central PMCID: PMCPMC2754098.

36. Nouvenne A, Meschi T, Prati B, Guerra A, Allegri F, Vezzoli G, et al. Effects of a low-salt diet on idiopathic hypercalciuria in calcium-oxalate stone formers: a 3-mo randomized controlled trial. Am J Clin Nutr. 2010;91(3):565-70. Epub 2009/12/30. doi: 10.3945/ajen.2009.28614. PubMed PMID: 20042524.

37. Słojewski M, Czerny B, Safranow K, Droździk M, Pawlik A, Jakubowska $\mathrm{K}$, et al. Does smoking have any effect on urinary stone composition and the distribution of trace elements in urine and stones? Urol Res. 2009;37(6):317-22. Epub 2009/ 10/14. doi: 10.1007/s00240-009-0221-5. PubMed PMID: 19826801.

38. Detsyk O, Solomchak D. The impact of cigarette smoking, alcohol drinking and physical inactivity on the risk of urolithiasis occurrence and recurrence. Wiad Lek. 2017;70(1):38-42. PubMed PMID: 28343191.

39. Durak I, Sahin A, Perk H. Smoking, hair cadmium and urinary tract stones. Eur Urol. 1990;17(3):267-8. PubMed PMID: 2351195. 
40. Mortada WI, Sobh MA, El-Defrawy MM. The exposure to cadmium, lead and mercury from smoking and its impact on renal integrity. Med Sci Monit. 2004;10(3):CR112-6. Epub 2004/03/01. PubMed PMID: 14976454.

41. Tamadon MR, Nassaji M, Ghorbani R. Cigarette smoking and nephrolithiasis in adult individuals. Nephrourol Mon. 2013;5 (1):702-5. Epub 2012/12/15. doi: 10.5812/numonthly.5251. PubMed PMID: 23577335; PubMed Central PMCID: PMCPMC3614330.

42. Ward KD, Klesges RC. A meta-analysis of the effects of cigarette smoking on bone mineral density. Calcif Tissue Int. 2001;68(5):259-70. PubMed PMID: 11683532; PubMed Central PMCID: PMCPMC5352985.

43. Jutberger H, Lorentzon M, Barrett-Connor E, Johansson H, Kanis JA, Ljunggren $\mathrm{O}$, et al. Smoking predicts incident fractures in elderly men: Mr OS Sweden. J Bone Miner Res. 2010;25(5):1010-6. doi: 10.1359/jbmr.091112. PubMed PMID: 19929437.

44. Walker LM, Preston MR, Magnay JL, Thomas PB, E1 Haj AJ. Nicotinic regulation of $\mathrm{c}$-fos and osteopontin expression in human-derived osteoblast-like cells and human trabecular bone organ culture. Bone. 2001;28(6):603-8. PubMed PMID: 11425648.

45. Krall EA, Dawson-Hughes B. Smoking increases bone loss and decreases intestinal calcium absorption. J Bone Miner Res. 1999;14(2):215-20. doi: 10.1359/jbmr.1999.14.2.215.PubMed PMID: 9933475.

46. Tankó LB, Christiansen C. An update on the antiestrogenic effect of smoking: a literature review with implications for researchers and practitioners. Menopause. 2004;11(1):104-9. doi:
10.1097/01.GME.0000079740.18541.DB. PubMed PMID: 14716190.

47. Cheema B, Abas H, Smith B, O'Sullivan A, Chan M, Patwardhan $\mathrm{A}$, et al. Progressive exercise for anabolism in kidney disease (PEAK): a randomized, controlled trial of resistance training during hemodialysis. J Am Soc Nephrol. 2007;18(5): 1594-601. Epub 2007/04/04. doi: 10.1681/ASN.2006121329. PubMed PMID: 17409306.

48. Belardinelli R, Georgiou D, Cianci G, Purcaro A. 10-year exercise training in chronic heart failure: a randomized controlled trial. J Am Coll Cardiol. 2012;60(16):1521-8. Epub 2012/09/19. doi: 10.1016/j.jacc.2012.06.036. PubMed PMID: 22999730.

49. Sorensen MD, Chi T, Shara NM, Wang H, Hsi RS, Orchard T, et al. Activity, energy intake, obesity, and the risk of incident kidney stones in postmenopausal women: a report from the Women's Health Initiative. J Am Soc Nephrol. 2014;25(2): 362-9. Epub 2013/12/12. doi: 10.1681/ASN.2013050548. PubMed PMID: 24335976; PubMed Central PMCID: PMCPMC3904570.

50. Ferraro PM, Curhan GC, Sorensen MD, Gambaro G, Taylor EN. Physical activity, energy intake and the risk of incident kidney stones. J Urol. 2015;193(3):864-8. Epub 2014/09/16. doi: 10.1016/j.juro.2014.09.010. PubMed PMID: 25229560; PubMed Central PMCID: PMCPMC4378568.

51. Gur A, Sarac AJ, Nas K, Cevik R. The relationship between educational level and bone mineral density in postmenopausal women. BMC Fam Pract. 2004;5:18. Epub 2004/09/06. doi: 10.1186/1471-2296-5-18.PubMed PMID: 15350210; PubMed Central PMCID: PMCPMC517940.

\title{
RIZIČNI ČIMBENICI I KOŠTANA MASA U BOLESNIKA S RECIDIVIRAJUĆOM UROLITIJAZOM: PRESJEČNO ISTRAŽIVANJE NA 144 ISPITANIKA
}

\author{
I. Maric, T. Kizivat, M. Smolic, R. Smolic, T. Opačak-Bernardi, K. Šolic, H. Roguljić, \\ J. Milas Abic, A. Tucak i I. Mihaljević
}

Bolesnici s urolitijazom, osobito oni s hiperkalciurijom, imaju smanjenu koštanu mineralnu gustoću (bone mineral density, BMD). Rizični čimbenici gubitka koštane mase su uznapredovala dob, sjedilački način života, pušenje i smanjen unos kalcija. Cilj našeg istraživanja bio je ustanoviti povezanost rizičnih čimbenika i dnevnog unosa mlijeka i mliječnih prerađevina $s$ odrednicama BMD u bolesnika s recidivirajućom kalcijskom urolitijazom te ih usporediti sa zdravim ispitanicima. Istraživanje je provedeno na Zavodu za mineralni metabolizam Medicinskog fakulteta u Osijeku. U istraživanju su sudjelovala 144 ispitanika, od čega 56 bolesnika s recidivirajućom kalcijskom urolitijazom i 78 zdravih ispitanika. BMD je određen metodom dvoenergetske apsorpciometrije $\mathrm{X}$ zraka (DXA). Podatci o čimbenicima rizika dobiveni su anketnim upitnikom, a unos hrane je ocijenjen osobnim intervjuom koji je uključivao pitanja o unosu mlijeka i mliječnih proizvoda. Snižen BMD zabilježen je u 44,64\% bolesnika s recidivirajućom urolitijazom i u 35,90\% zdravih ispitanika. Bolesnici s recidivirajućom urolitijazom konzumirali su znatno manje mlijeka i mliječnih proizvoda u odnosu na zdrave ispitanike. Nepotrebna je preporuka smanjenog unosa kalcija bolesnicima s recidivirajućom urolitijazom zbog utjecaja na gubitak koštane mase, a DXA treba biti dio rutinske procjene bolesnika s recidivirajućom urolitijazom.

Ključne riječi: urolitijaza; mineralna gustoća kosti; tjelesna težina; indeks tjelesne mase; tjelesna aktivnost; pušenje; unos kalcija 